\title{
Adresaci uzasadnienia sądowego a jego treść (przykład sądownictwa administracyjnego) ${ }^{1}$
}

\section{Wprowadzenie}

Uzasadnianie następujące $\mathrm{w}$ toku stosowania prawa przez sądy jest zjawiskiem wielowymiarowym. Składa się na nie, z zasady, szereg komunikatów (poprzedzonych odpowiednimi procesami myślowymi), kierowanych do mniej lub bardziej precyzyjnie oznaczonych podmiotów ${ }^{2}$. Najbardziej sformalizowane i ustrukturalizowane, a przez to wywołujące najistotniejsze skutki zewnętrzne, jest pisemne uzasadnienie orzeczenia. Wydaje się, że nie mniej doniosłe znaczenie ma również ustne przedstawienie motywów wyroku. Obok tych dwóch podstawowych form komunikowania się sądu z podmiotami mającymi w stosunku do niego charakter zewnętrzny można dostrzec różne rodzaje komunikatów wpadkowych, dotyczących m.in. poszczególnych decyzji cząstkowych - walidacyjnych czy interpretacyjnych, które nie są werbalizowane. Adresatem ich uzasadnienia jest bowiem sam sędzia (kierujący w ten sposób wypowiedź do siebie samego), bądź też tworzone są one w mniej formalny, niż w pozostałych przypadkach, sposób.

Sposób postrzegania uzasadnień różni się w zależności od tego, czy mowa o refleksji naukowej, czy o typowym odbiorze społecznym (w którym uzasadnienie traktowane jest jako jednostkowa wypowiedź, nie zaś przedmiot systematycznych badań). O ostatniej z tych perspektyw będzie jeszcze szerzej mowa w dalszej części tekstu. W tym miejscu warto natomiast poświęcić kilka słów optyce naukowej. Odnosi się ona do uzasadnień zarówno w ramach problemów dogmatycznych (jako czynność procesowa), jak i teorii prawa (element procesu jego stosowania), a także logiki prawniczej (wyjaśnianie, dowodzenie itp.),

1 Praca naukowa finansowana ze środków budżetowych na naukę w latach 2012-2015 jako projekt badawczy w ramach programu pod nazwą „Diamentowy Grant”.

2 Szerzej na ten temat: I. Rzucidło, Wielowymiarowość uzasadnienia decyzji stosowania prawa, [w:] Marta Żuralska (red.), Interdyscyplinarne ujęcie prawa. Materiaty ogólnopolskiej konferencji naukowej „Prawo i...”. Zasadność interdyscyplinarnego ujęcia prawa. Warszawa, 2-3 grudnia 2011 r., Warszawa 2013, s. 39-53. 
teorii argumentacji, komunikacji czy dyskursu33. W każdym z tych przypadków zakres znaczeniowy pojęcia „uzasadnienie” przedstawia się odmiennie, tak jak różne jest postrzeganie jego roli w stosunku do adresatów.

Przenikanie się - widoczne wyraźnie przede wszystkim w uzasadnieniu pisemnym - elementów dogmatycznoprawnych oraz teoretycznoprawnych, logiki prawniczej i socjologii prawa nie budzi wątpliwości. Istotne wydaje się jednak uwzględnienie szeregu czynników pozaprawnych, kształtujących sposób i formę uzasadniania. Dostrzegalne prima facie związki z językoznawstwem oraz naukami kognitywnymi pozwalają na znaczące wzbogacenie warsztatu, który może posłużyć do opisu działań podejmowanych przez podmiot decyzyjny. Nie bez znaczenia dla interdyscyplinarnego wymiaru uzasadniania są również związki z psychologią i socjologią oraz kulturoznawstwem. Dyscypliny te dobrze odpowiadają specyfice przedmiotu badań, jakim jest uzasadnienie.

Podstawowym celem niniejszego opracowania jest zaprezentowanie katalogu odbiorców uzasadnienia sądowego oraz ukazanie ich szerokiego wpływu na kształt uzasadniania w procesie stosowania prawa, a w szczególności uzasadnienia jako jego wytworu ${ }^{4}$.

Dalsze uwagi będą oparte na przykładach zaczerpniętych z orzecznictwa sądowoadministracyjnego. Wynika to z dwóch powodów. Na wybór ten miał wpływ fakt, że zdecydowana większość orzeczeń sądów administracyjnych została opublikowana w oficjalnej, ogólnodostępnej bazie, co ułatwia obserwację oraz pozwala nadać jej bardziej pełny charakter. Obok tej czysto metodologicznej przyczyny, drugim powodem wyboru pola badań jest wyraźna odmienność stosowania prawa przez sądy administracyjne (wynikająca m.in. ze specyfiki sądu prawa, kontrolującego legalność działań określonych podmiotów) oraz dość duża elastyczność stosowanych przez nie metod wykładni, przy świadomości multicentryzmu współczesnego systemu prawa ${ }^{5}$.

\section{Uwagi terminologiczne}

Krótkiego wyjaśnienia wymaga znaczenie pojęć użytych w tekście. Nie zostały one wykorzystane w powiązaniu z żadną konkretną teorią czy nurtem filozofii prawa. Są rozumiane autonomiczne i definiowane na nowo na potrzeby

3 Zob. również: M. Zieliński, Z. Ziembiński, Uzasadnianie twierdzeń, ocen i norm w prawoznawstwie, Warszawa 1988.

4 Na marginesie zostanie jedynie zasygnalizowana kwestia sędziego jako autora uzasadniania i adresata uzasadnienia.

5 Na temat specyfiki sądownictwa administracyjnego zob. I. Rzucidło, Uzasadnienie orzeczenia a prawo do sqdu (kontekst sqdownictwa administracyjnego), [w:] eadem (red.), Administracja i prawo administracyjne w kontekście ochrony praw człowieka, Lublin 2012, s. 108 i n. oraz L. Leszczyński, Orzekanie przez sqdy administracyjne a kontrola wyktadni prawa, „Zeszyty Naukowe Sądownictwa Administracyjnego" 2010, nr 5/6, s. 267 i n.; E. Łętowska, Multicentryczność współczesnego systemu prawa i jej konsekwencje, „Państwo i Prawo” 2005, z. 4, passim. 
omawianej problematyki. Najczęściej więc pojęcie występujące w języku potocznym wypełniono nową treścią, nieznacznie ukierunkowując semantykę na jak najpełniejsze oddanie istoty tytułowego zagadnienia.

Adresat uzasadnienia jest podmiotem, do którego uzasadnienie kierowane jest wprost, bezpośrednio. Co prawda, sposób kierowania przekazu w uzasadnieniu oraz krąg podmiotów, do których jest ono adresowane, zależy od wielu czynników (nie tylko prawnych, lecz także pozajurydycznych), niemniej jednak najważniejszym kryterium pozostaje świadomość autora uzasadnienia ${ }^{6}$ co do zakresu możliwego oddziaływania jego argumentacji oraz chęci skierowania uzasadnienia (z pobudek obiektywnych bądź subiektywnych) do określonych podmiotów. Możliwe jest bowiem intencjonalne zawężenie (najczęściej) lub poszerzenie kręgu adresatów w stosunku do tego, który pozostaje w świadomości sędziego w konkretnym przypadku. Należy bowiem zaznaczyć, że katalog adresatów konstruowany jest każdorazowo od nowa (osobno dla każdego uzasadnienia) 7 . Tym właśnie adresaci różnią się od odbiorców uzasadnienia. Ci ostatni są podmiotami stykającymi się z uzasadnieniem de facto, bez ukierunkowanej w ich stronę intencji autora uzasadnienia, często występującymi poza jego świadomością (rzecz jasna, nie zawsze zdaje on sobie sprawę, kto może mieć kontakt $\mathrm{z}$ danym uzasadnieniem). Każdy zatem adresat jest odbiorcą, lecz nie każdy odbiorca-ze wględu na szerszy zakres znaczeniowy pojęcia - adresatem uzasadnienia. Rozróżnienie to jest o tyle istotne, że w znaczącej mierze krąg odbiorców sporządzanego przez sędziego uzasadnienia ograniczony jest do jego adresatów, a to - jak zostanie wykazane poniżej - jakie podmioty znajdują się w tym kręgu, istotnie determinuje sposób sporządzania uzasadnienia oraz jego treść.

Ważne z punktu widzenia metodologicznego wydaje się również rozróżnienie uzasadnienia i uzasadniania. Uzasadnienie sądowe ma postać pisemną $\mathrm{i}$ jest dokumentem urzędowym (lub też przyjmuje formę ustnych motywów wyroku). Wszystko, co związane jest z eksponowaniem racji stojących za danym rozstrzygnięciem, a wykracza poza tę kategorię, jest uzasadnianiem.

6 Pojęcia ,autor uzasadniania” oraz „sędzia” używane są w opracowaniu zazwyczaj wymiennie, ze względu na to, że podmioty te (nie zawsze tożsame, np. gdy autorem projektu uzasadnienia jest asystent sędziego czy aplikant) w odbiorze zewnętrznym nie są z reguły rozróżniane. O roli asystenta sędziego zob. E. Łętowska, K. Pawłowski, Gorzkie owoce ze szkoły Hesperyd, „Europejski Przegląd Sądowy” 2011, nr 2, s. 59-60 oraz A. Liptak, Justices long on words but short on guidance, „New York Times”, 17.11.2010.

7 Należy przy tym wskazać, że adresaci, do których kierowane jest uzasadnienie, mogą być określani jako adresaci bezpośredni, zaś podmioty, których istnienia sędzia ma świadomość, lecz nie stają się one dla niego tymi, do których chce kierować swoją wypowiedź zawartą w uzasadnieniu (co często nie oznacza, iż faktycznie nie jest ona również kierowana, jednak ma to drugorzędne znaczenie) - jako adresaci pośredni. Nie wszyscy odbiorcy mają zatem w każdym przypadku wpływ na treść uzasadnienia, podmiotami tymi są tylko adresaci. Podobnie L. Leszczyński wyróżnia adresatów aktualnych i potencjalnych - zob. L. Leszczyński, Zagadnienia teorii stosowania prawa. Doktryna i tezy orzecznictwa, Kraków 2004, s. 79 i n. 
Prezentowane rozumienie uzasadnienia ujmowane jest apragmatycznie - jako rezultat procesu uzasadniania w postaci określonego zbioru wypowiedzi językowych, najczęściej utrwalonych w taki sposób, aby podmiot inny niż twórca uzasadnienia mógł zapoznać się z jego treścią. Pojęcie uzasadnienia z zasady odnosi się do decyzji finalnej, która na podstawie zastosowanych norm prawnych wiążąco ustala skutki prawne faktu uznanego za udowodniony ${ }^{8}$. Uzasadnienie jest więc tylko (i aż) elementem wieńczącym dany etap postępowania, jednak nie jest jedynym przejawem przedstawienia sposobu odnajdywania podstaw decyzji procesu stosowania prawa.

$\mathrm{W}$ przeciwieństwie do uzasadnienia, uzasadnianie ma natomiast charakter procesu (składającego się z jednej lub wielu czynności) i cechuje się dynamiką. Determinuje to z kolei przeniesienie środka ciężkości na cechy mniej formalne i strukturalne, prowadząc do silniejszego akcentowania możliwości reakcji na indywidualny odbiór przejawów tego procesu. Tak rozumiane uzasadnianie składa się przede wszystkim z refleksji dotyczącej szeregu cząstkowych decyzji walidacyjnych $\mathrm{i}$ interpretacyjnych podejmowanych $\mathrm{w}$ toku procesu stosowania prawa. Przebiegają one w umyśle interpretatora i w chwili swojego następowania nie znajdują zazwyczaj szerszego wyrazu zewnętrznego. Dopiero po zsumowaniu i syntezie procesy te ujawniają się in foro externo w postaci orzeczenia oraz ustnego i pisemnego uzasadnienia.

Istotne wydaje się także rozróżnienie uzasadnienia sędziowskiego i sądowego. Pisemne uzasadnienie orzeczenia (ale także podanie ustnych motywów wyroku) z reguły tworzone jest przez sędziego sprawozdawcę?. Pozostali członkowie składu orzekającego mają, co prawda, wpływ na jego treść, jednak zazwyczaj zapoznają się jedynie z tekstem uzasadnienia (co łączyć się może $\mathrm{z}$ wprowadzeniem poprawek $)^{10}$. Przedstawienie stanowiska odmiennego, zarówno w stosunku do sentencji, jak i uzasadnienia, możliwe jest poprzez zgłoszenie voti separati, posiadającego osobne uzasadnienie, stojącego w opozycji do zdania większości. Umożliwia ono indywidualizację stanowiska sędziego orzekającego w składzie wieloosobowym ${ }^{11}$. Uzasadnienia takie (zarówno większościowe, jak i odrębne) określa się jako uzasadnienie sędziowskie. Pochodzi

${ }^{8}$ K. Płeszka, Uzasadnianie decyzji interpretacyjnych przez ich konsekwencje, Kraków 1996, s. 17.

9 Regulamin wewnętrznego urzędowania wojewódzkich sądów administracyjnych, rozporządzenie Prezydenta Rzeczypospolitej Polskiej z 18 września 2003 r., Dz. U. 2003, nr 169, poz. 1646.

${ }^{10} \mathrm{~W}$ przypadku braku jednomyślności uzasadnienie powinno zawierać tylko te elementy, co do wystąpienia których przekonana jest większość składu orzekającego. Por. wyrok Sądu Najwyższego z 31 października 1973 r., III CRN 249/73, OSNC 1974, nr 7-8, poz. 140.

${ }^{11}$ W szczególności wtedy, gdy treść zdań odrębnych publikowana jest tak samo, jak treść rozstrzygnięcia i uzasadnienia uzyskanego większością głosów, m.in. z podaniem nazwiska sędziego je zgłaszającego, tak jak to czyni Naczelny Sąd Administracyjny czy Trybunał Konstytucyjny. 
ono bowiem od konkretnego autora, będącego jednostką odrębną w stosunku do sądu (oczywiście także wówczas, gdy orzeczenie wydane zostaje jednoosobowo), ale zarazem wchodzącego w jego skład.

Uzasadnienie sądowe jest natomiast kategorią nieco szerszą. Argumentacja w nim zawarta przedstawiana jest w imieniu sądu jako sztucznie wykreowanego przez prawodawcę konstruktu sprawującego wymiar sprawiedliwości. Zawiera $\mathrm{w}$ sobie także pewien element pragmatyczny, wynikający ze specyfiki pracy w sądzie, w którym realny wpływ na kształt uzasadnienia może mieć także osoba spoza składu orzekającego. Szkice uzasadnień przygotowuje często asystent sędziego, niekiedy praktykant czy aplikant - a więc osoba niebiorąca bezpośredniego i czynnego udziału w wydaniu rozstrzygnięcia. Niemniej jednak po podpisaniu przez skład orzekający powstałe $\mathrm{w}$ ten sposób uzasadnienie zostaje zrównane $\mathrm{z}$ uzasadnieniem pochodzącym bezpośrednio od sędziego - $\mathrm{i}$ tak też jest traktowane przez system prawa. W praktyce adresaci uzasadnienia najczęściej nie mają świadomości, kto jest jego faktycznym twórcą.

\section{Odbiorcy uzasadniania sądowego}

Jak już wspomniano, kluczowe znaczenie dla identyfikacji kręgu adresatów uzasadnienia ma świadomość i wola jego autora. Jeżeli zdaje on sobie sprawę $\mathrm{z}$ wagi prawidłowego uzasadniania tylko w podstawowym zakresie, konstruuje uzasadnienie tak, by w pożądany sposób dotarło do adresatów bezpośrednich i zostało przez nich prawidłowo odczytane. Natomiast podmiot, którego cechuje bardziej rozwinięte poczucie dbałości o społeczny wymiar prezentowanej argumentacji, uzasadniając wydaną decyzję, stara się akcentować także te argumenty, które przemówią do adresatów pośrednich i pozostałych odbiorców ${ }^{12}$. Odpowiada on tym samym na społeczną potrzebę legitymizacji obowiązującego porządku prawnego, przedstawiając na tyle szerokie, a jednocześnie precyzyjne, stanowisko, by możliwe było formułowanie rzeczowych komentarzy co do zasadności podjętego rozstrzygnięcia. Wyróżnienie podmiotów mogących być odbiorcami uzasadnienia oraz konieczność dostosowania i zindywidualizowania rodzaju argumentów uzasadnienia z perspektywy poszczególnych kategorii adresatów stanowi bez wątpienia jedno $\mathrm{z}$ istotnych zadań sądu.

Do katalogu odbiorców uzasadnienia zaliczyć można: strony postępowania, administrację publiczną, sądy wyższej i niższej instancji, skład orzekający, inne składy orzekające tego samego sądu, inne sądy i trybunały (w tym sądy międzynarodowe), środowisko prawnicze, przedstawicieli nauki prawa, społeczeństwo, media, prawodawcę, glosatora, publiczność na sali rozpraw, a także

${ }^{12}$ Por. np. wyrok Naczelnego Sądu Administracyjnego z 18 maja 2011 r., I OSK 1323/10. Wszystkie przywołane orzeczenia sądów administracyjnych dostępne w oficjalnej bazie orzeczeń (CBOSA) pod adresem: http://orzeczenia.nsa.gov.pl/cbo/query. 
samego sędziego sprawozdawcę. Wyliczenie to zawiera oczywiście tylko najbardziej typowe podmioty i nie wyczerpuje wszystkich sytuacji, jakie mogą wystąpić w praktyce. Już samo istnienie tych co najmniej piętnastu kategorii adresatów nie pozostawia jednak wątpliwości, że adresowanie uzasadnienia do wszystkich w równym stopniu i w każdej sprawie jest niezwykle utrudnione. Co więcej, poszczególne kategorie odbiorców wzajemnie się przenikają i uzupełniają, toteż ich katalog ma raczej charakter typologiczny. Tworzenie uzasadnienia jako komunikatu sądu skierowanego do - w pewnym tylko zakresie precyzyjnie określonego i uświadomionego - odbiorcy wydaje się zatem kwestią wysoce złożoną, wymagającą znacznych umiejętności i odpowiedniego odczytania jej szerokiego kontekstu pozaprawnego, a także biegłości prawnej i argumentacyjnej (często większej, niż można by sądzić prima facie). Nieco bardziej szczegółowe zaprezentowanie każdego ze wskazanych odbiorców znajdzie miejsce przy opisywaniu uzasadnienia pisemnego, dla kształtu którego mają oni największe znaczenie.

\section{Uzasadnienie pisemne}

Przejawem zależności pomiędzy postrzeganym katalogiem adresatów a sposobem konstruowania uzasadnienia jest nie tylko sposób posługiwania się środkami językowymi, lecz także jego obszerność czy kompozycja. Pomimo wielu istotnych odrębności konstruowanie uzasadnienia pisemnego z perspektywy jego poszczególnych adresatów wydaje się realizować pewne kierunki oddziaływania, wspólne dla wszystkich ich grup, które - dla klarowności wywodu - zostaną zaprezentowane w pierwszej kolejności w każdej z dalej omówionych części. Następnie, w ramach zilustrowania tych strategii najbardziej wyrazistymi przykładami, zostaną wskazane elementy różnicujące i konkretyzujące, odnoszące się do najbardziej specyficznych typów adresatów występujących w danej sytuacji. Ze względu na ramy tego opracowania jedynie zasygnalizowane zostaną natomiast odrębności w konstruowaniu uzasadnień przez wojewódzkie sądy administracyjne i NSA oraz charakterystyka ich adresatów.

\subsection{Częséć historyczna ${ }^{13}$}

Rozważania podmiotów stosujących prawo na etapach poprzedzających wydanie orzeczenia stają się elementem rysu historycznego sprawy przy jej rozpatrywaniu przez sąd. Część historyczna nie jest tylko opowieścią o tym, co działo się w sprawie, ale - ze względu na typ sądownictwa administracyjnego - wyznacza stan prawny służący do oceny legalności działań organów administracji publicznej i sądu pierwszej instancji. Jest ona w pewien sposób przedpolem dla

${ }^{13}$ Część historyczna bywa określana w różny sposób, m.in. jako stan faktyczny czy rys historyczny. 
subsumpcji i innych faz procesu stosowania prawa, mających swoje odzwierciedlenie w części prawnej, i służy pomocniczo legitymizacji rozstrzygnięcia. Charakterystyczną cechą sposobu ujmowania części historycznej jest jej formułowanie pod kątem przyjętego rozstrzygnięcia ${ }^{14}$ (ze względu na następczość tworzenia pisemnego uzasadnienia w stosunku do wydania orzeczenia w sprawie), najczęściej również z uwzględnieniem zarzutów podnoszonych przez stronę. Stan faktyczny, będący częścią uzasadnienia, staje się partykularnym instrumentem swoistego dialogu sądu z adresatami jego komunikatu ${ }^{15}$.

W zakresie wpływu, jaki poszczególni adresaci wywierają na konstruowanie części historycznej, punktem szczególnie newralgicznym wydaje się przytoczenie zarzutów środka odwoławczego, które jest stałym elementem wszystkich uzasadnień sądowoadministracyjnych - w praktyce często dosłownie, bez syntezy czy parafrazy ${ }^{16}$. Z całą pewnością taki zabieg - mający z założenia służyć pokazaniu stronie, iż jej wątpliwości zostały potraktowane poważnie oraz zbadane drobiazgowo i wnikliwie - paradoksalnie budzi przekonanie o braku czasu i niedostatecznej refleksji nad treścią zarzutów ${ }^{17}$. Kluczowe znaczenie ma jednak w tym wypadku sposób odniesienia się do nich w części prawnej uzasadnienia - to on ostatecznie decyduje bowiem o wartości argumentacyjnej wywodu. Warto przy tym zauważyć, że powoływanie zarzutów in extenso ${ }^{18}$ (a czasami nawet in crudo ${ }^{19}$ może wynikać ze sposobu ich zredagowania przez wnoszącego środek zaskarżenia i niemożności ich pełnego zrozumienia przez sąd. Stanowi to wówczas rodzaj taktyki uzasadniania, pozwalającej na stworzenie pozorów, iż skoro znalazły się one w części historycznej, to zostały rozważone. Sprzyja to występowaniu zjawiska, które można określić jako „legitymizację przez pozory” - a więc operowaniu treścią uzasadnienia w sposób mający stworzyć u adresata wrażenie wyczerpującej

${ }^{14}$ Także w sytuacjach, w których orzeczenie ma charakter formalny (jak np. przy cofnięciu skargi kasacyjnej) porusza się jedynie kwestie proceduralne, nie zaś przytacza zarzuty podniesione przez stronę. Zob. orzeczenia o sygn. akt II FSK 1840/11, II OSK 347/13, II GSK 376/12, II FSK 755/13 oraz II OZ 384/13 (bezprzedmiotowość wstrzymania wykonania zaskarżonej decyzji ze względu na wcześniejsze wydanie wyroku w sprawie).

${ }^{15}$ Oczywiście, nie dialogu na równych prawach.

${ }^{16}$ M. Domagalski, Kopiuj/wklej w wyroku, „Rzeczpospolita”, 20.12.2011.

${ }^{17}$ Niekiedy sprowadza się to do powielenia fragmentów z decyzji administracyjnej i pism procesowych, co paradoksalnie staje się bronią obosieczną i działa na niekorzyść sądu tak czyniącego, gdyż - w braku syntezy dotychczasowych działań podejmowanych w sprawie - naraża go na zarzut niedokonania własnych rozważań co do okoliczności faktycznych. Zaobserwownie tej zależności przez czytelnika wymaga jednak kontaktu z aktami sprawy.

${ }^{18}$ Nieznacznie przetworzone zarzuty nie są rzadkością - por. wyroki o sygn. akt II OSK 2259/11, II OSK 1393/12, I GSK 1258/11.

${ }^{19}$ Powoływanie zarzutów właściwie nieprzetworzonych możliwe jest do zaobserwowania po analizie stylu pisania, sposobu powoływania aktów prawnych oraz wskazywania stron postępowania (np. stosowanie wielkich i małych liter w różnych fragmentach stanu faktycznego). 
i pogłębionej refleksji ${ }^{20}$. Mały wkład własny sądu w tych sytuacjach przekłada się na długość części historycznej uzasadnienia, konstruowanej z oczywistych względów bardziej rozwlekle, niż miałoby to miejsce w przypadku streszczania i wyciągnięcia esencji okoliczności faktycznych.

Adresowanie uzasadnienia do stron postępowania oraz sądu wyższej i niższej instancji (w przypadku uchylenia orzeczenia) sprzyja formułowaniu jego poszczególnych elementów w sposób bardziej skondensowany, niż ma to miejsce w przypadku pozostałych adresatów. Nie jest bowiem konieczne szczegółowe informowanie ich o przebiegu postępowania w sprawie, $\mathrm{z}$ uwzględnieniem wypowiedzi każdego z uczestniczących w nim podmiotów. Jest ono wymagane tylko w takim zakresie, w jakim sąd ma za zadanie skontrolować ustalenia faktyczne w sprawie w części prawnej, gdyż sami są jednymi z jego uczestników.

Jeśli uzasadnienie jest kierowane do innych składów tego samego sądu (zwłaszcza z myślą o upowszechnieniu treści rozstrzygnięcia i przemawiającej za nim motywacji), zarysowanie stanu faktycznego sprawy może zostać wykorzystane w celu ułatwienia kształtowania linii orzeczniczej. Część historyczna służy w tym przypadku wskazaniu, na czym polega istota sprawy, w jakim zakresie różni się ona od spraw rozstrzyganych dotychczasowo lub w czym tkwi walor nowości. W ten sposób możliwe staje się pokazanie, w jakim zakresie pogląd wyrażony w uzasadnieniu mieści się w dotychczasowej linii orzeczniczej, a w jakim wnosi do niej coś nowego lub od niej odchodzi.

Podobnie sytuacja ma się w przypadku adresowania uzasadnienia do innych sądów i trybunałów. Stan faktyczny konstruowany jest wówczas pod kątem wykorzystania konkretnego rozstrzygnięcia przez inne podmioty orzekające, mające charakter zewnętrzny w stosunku do sądu sporządzającego dane uzasadnienie. Część historyczna staje się wtedy - wraz z częścią prawną - ważnym instrumentem dialogu wewnątrz władzy sądowniczej ${ }^{21}$.

Wydaje się także, iż na sposób konstruowania stanu faktycznego sprawy może mieć wpływ sporządzanie go ze świadomością, że będzie ono czytane w szerszych kręgach prawniczych, w szczególności przez praktyków. Biorąc pod uwagę, że odbiorcą uzasadnienia będą profesjonaliści - oceniający jego treść i konstrukcję lub korzystający z niego na potrzeby własnych wypowiedzi

${ }^{20}$ Detalicznemu przytaczaniu twierdzeń skarżącego sprzyja także zawężenie przez ustawodawcę kognicji sądu odwoławczego wyłącznie do granic środka zaskarżenia i treści podniesionych w nim zarzutów (ma to miejsce m.in. w postępowaniu kasacyjnym przed NSA).

${ }^{21}$ A. Kotowski, Dyskursywny model orzecznictwa - uwagi ogólne, [w:] L. Gardocki, J. Godyń, M. Hudzik, L. K. Paprzycki (red.), Dialog między sqdami i trybunałami, Warszawa 2010, passim; E. Łętowska, Udział trzeciej władzy w dyskursie społecznym - sqdy i trybunały najwyższych instancji, [w:] L. Nawacki, R. Hauser (red.), Państwo w stużbie obywateli. Księga jubileuszowa Jerzego Świqtkiewicza, Warszawa 2005, passim; B. Wojciechowski, Dyskursywny model sqdowego stosowania prawa - wybrane aspekty, [w:] J. Stelmach (red.), Filozofia prawa wobec globalizmu, Kraków 2003, passim. 
(uzasadnień, pism procesowych itd.) - autor części historycznej może starać się konstruować opis stanu faktycznego w sposób możliwie jasny i syntetyczny, ułatwiający lekturę i wyłowienie istoty rozstrzyganego problemu. Z drugiej strony, jak można się spodziewać, będzie on dążył do nasycenia części historycznej treścią, która pozwoli dostrzec elementy odróżniające orzeczenie od podobnych rozstrzygnięć oraz łatwo zorientować się w faktach, które stały się jego podstawą.

Podobnie rzecz się przedstawia w przypadku identyfikowania społeczeństwa jako adresata uzasadnienia. Sędzia ma zazwyczaj świadomość, iż jego przedstawiciele czerpią z orzeczeń sądowych informację o funkcjonowaniu prawa w praktyce, traktując często rozstrzygnięcia jako prawo per se (wzór zachowania) lub przynajmniej opierając się na orzeczeniach w swoich przewidywaniach co do kierunku stosowania danej normy prawnej. Mając świadomość społecznej wagi danego rozstrzygnięcia, autor uzasadnienia tworzy jego część faktyczną w taki sposób, by było ono jak najbardziej zrozumiałe i czytelne dla laika (oczywiście, nie do granic pozbawienia uzasadnienia charakteru dokumentu urzędowego). Przedstawia on w sposób uproszczony istotę rozpatrywanego zagadnienia, ewentualnie w sprawach budzących wzmożone zainteresowanie społeczne prezentuje przebieg postępowania i stanowiska stron krok po kroku, zarazem jednak syntetycznie i klarownie.

Podobnie, aczkolwiek z pewną odrębnością, sytuacja przedstawia się w przypadku mediów, traktowanych jako osobny adresat i pośrednik pomiędzy sądem a innymi odbiorcami, w szczególności społeczeństwem. Część faktyczna jest wtedy tworzona $\mathrm{z}$ jednej strony syntetycznie $\mathrm{i}$ jasno, $\mathrm{z}$ drugiej natomiast $-\mathrm{z}$ wyeksponowaniem informacji, które mogły zostać przez media pominięte, a miały wpływ na wydane orzeczenie. Co również istotne, przy tej kategorii adresata niezwykle istotne jest ważenie słów i precyzyjne posługiwanie się nimi, gdyż często przekaz medialny opiera się na fragmentach wyciętych z tekstu uzasadnienia, co stwarza obawę opacznego zrozumienia treści uzasadnienia przez konsumentów informacji medialnej.

\subsection{Część prawna ${ }^{22}$}

W przypadku części prawnej pomiędzy treścią uzasadnienia a katalogiem adresatów występuje bezpośrednia relacja - która, jak się wydaje, jest znacznie silniejsza niż w przypadku części historycznej. Kluczowe znaczenie dla konstrukcji uzasadnienia ma natomiast nie jego rzeczywiste rozumienie i postrzeganie, lecz przekonanie autora co do tego, jak będzie ono odbierane ${ }^{23}$.

${ }^{22}$ Część ta określana jest również m.in. jako uzasadnienie prawne.

${ }^{23}$ Przypuszczenie to oparte jest na sposobie, w jaki autor uzasadnienia postrzega adresatów swojego przekazu - nie jako jednostki, lecz całą grupę. Na podstawie wyobrażenia o idealnym przedstawicielu i jego cechach (ewentualnie kilku przedstawicielach, choć dostępne są ogólne badania o postrzeganiu wymiaru sprawiedliwości) oraz dotychczasowych doświadczeń dokonuje generalizacji i projekcji jego cech na konkretny rodzaj adresata jako całą grupę jednostek, tworząc względnie jednorodny - zależnie od typu adresata - obraz całej kategorii. 
Uzasadnienie prawne jest właściwie jedynym polem własnej, samodzielnej czy autorskiej wypowiedzi sądu (w przeciwieństwie jednak do stanu faktycznego, którego konstrukcja zdominowana jest przez wcześniejsze wypowiedzi innych podmiotów). Sąd jest, co prawda, związany przepisami prawa procesowego, określającymi ogólnie składniki uzasadnienia, wypełnienie ich treścią należy jednak, rzecz jasna, do sądu ${ }^{24}$. To właśnie w zdecydowanej mierze na tej części uzasadnienia spoczywa ciężar perswazji i legitymizacji całego orzeczenia oraz realizacja szeregu innych funkcji uzasadnienia ${ }^{25}$. Wszystkie te funkcje da się sprowadzić, ogólnie rzecz biorąc, do różnych wymiarów dialogu sądu z innymi podmiotami procesu stosowania prawa.

W przypadku uzasadnienia prawnego można zaobserwować dwie główne strategie jego tworzenia, zdeterminowane postrzeganiem katalogu adresatów ${ }^{26}$.

Pierwszą z tych strategii można określić jako dyskursywną ${ }^{27}$. Polega ona na potwierdzaniu (aprobowaniu) lub kwestionowaniu argumentów poprzez odnoszenie się do nich jeden po drugim. Jest ona więc silnie ukierunkowana na komentowanie przez formułowanie argumentów. Co oczywiste, strategia ta jest najsilniej reprezentowana $\mathrm{w}$ tych fragmentach uzasadnienia, których głównym adresatem są strony postępowania. Warunkiem pełnej dyskursywności takiego uzasadnienia jest przytoczenie wypowiedzi strony - w szczególności formułowanych przez nią zarzutów - w części historycznej i odniesienie się do każdego $\mathrm{z}$ nich $\mathrm{w}$ części poświęconej rozważaniom prawnym ${ }^{28}$. W skrajnej postaci autor uzasadnienia odpowiada wówczas na każdy z przytoczonych argumentów, na-

${ }^{24}$ Oczywiście, część prawna jest również miejscem na komentowanie ustaleń faktycznych w sprawie, lecz jej esencją stają się rozważania o innym charakterze. Sąd bowiem ma za zadanie - co do zasady - przedstawić tu uzasadnienie dla poszczególnych elementów procesu stosowania prawa: ustalenia stanu faktycznego i prawnego sprawy, subsumpcji oraz ustalenia konsekwencji prawnych. Nie odbywa się to jednak wprost, co oznacza, że autor uzasadnienia najczęściej nie nazywa tych poszczególnych etapów, nie anonsuje ich dokonania, lecz po prostu je realizuje.

${ }^{25}$ I. Rzucidło, Funkcje uzasadnienia sqdowego, ,Studenckie Zeszyty Naukowe” 2011, nr 21, passim; Z. Wojnicki, Funkcje uzasadnień decyzji sadowych, „Studia Prawno-Ekonomiczne” 1989, nr XLIII, passim.

${ }^{26}$ Można zaobserwować inne strategie, jednak niezwiązane bezpośrednio ze sposobem postrzegania adresatów uzasadnienia, np. strategię normatywną. Wynika ona wprost z przepisów prawa i wzorów postępowania utartych na gruncie jego stosowania. Sąd w pewnych sytuacjach zobowiązany jest bowiem do działania z urzędu (np. NSA w przypadku nieważności postępowania). Ponadto, logiczna kolejność rozpoznawania zarzutów - czy szerzej - uchybień lub kwestii mających znaczenie w sprawie, najpierw proceduralnych, następnie merytorycznych (a w przypadku dostrzeżenia tych pierwszych - zaprzestanie dalszego poszukiwania, lecz uchylenie kontrolowanej decyzji stosowania prawa z tych powodów) przez wzgląd na ekonomię procesową, ma swoje odzwierciedlenie w uzasadnieniu. Silniej akcentuje to kontrolny charakter uzasadnienia i samego orzeczenia w stosunku do sądu niższej instancji oraz organu administracji publicznej. Uzasadnienie jest wówczas adresowane głównie do podmiotów kontroli instancyjnej.

${ }^{27}$ Choć nie w warunkach idealnej sytuacji mowy, przedstawionej przez J. Habermasa.

${ }^{28}$ Por. orzeczenia o sygn. akt II OZ 359/13, I FSK 840/12. 
wet najbardziej absurdalny czy nierzeczowy, wskazując własny kontrargument o charakterze stricte merytorycznym ${ }^{29}$. W ten sposób sąd daje przede wszystkim wyraz poważnemu potraktowaniu każdej rozpoznawanej sprawy oraz respektowi dla obywatela - wynikającemu z pozycji sądu w państwie demokratycznym.

Strategia dyskursywna stosowana jest także wówczas, gdy sąd ma świadomość, iż strona czy jej pełnomocnik (jako swoista subkategoria tego adresata) weryfikuje rozstrzygnięcie i na tej podstawie może formułować wnioski odwoławcze. Podobnie sytuacja przedstawia się w przypadku sądu wyższej instancji ${ }^{30}$ uchylającego wadliwą decyzję stosowania prawa, który wprost ocenia rozumowanie zawarte w kontrolowanej decyzji. Mając świadomość, że orzeczenie (a ściślej: motywy przytoczone na jego poparcie) może być przedmiotem kontroli innego organu, sąd będzie konstruował uzasadnienie w taki sposób, aby jak najpełniej przedstawić i wyjaśnić argumenty, które zaważyły na kształcie wydanego rozstrzygnięcia ${ }^{31}$.

Drugą strategię nazwać można monologiczną - przybiera ona bowiem postać pisemnego wywodu na temat danej instytucji prawnej mającej zastosowanie w sprawie lub jest własną propozycją rozwiązania występujących w niej zagadnień. Przypomina ona nieco rozwiązanie abstrakcyjnego kazusu, w którym sąd przedstawia swój pogląd w danej sprawie, ewentualnie z mniejszą lub większą dozą odniesień do realiów danego przypadku. Ma to zwłaszcza miejsce w sytuacji, w której autor uzasadnienia nie może - ze względu na zawiłość lub nierzeczowość sformułowania wypowiedzi podmiotów występujących w sprawie odnieść się do każdego zarzutu czy argumentu na jego potwierdzenie z osobna lub gdy znalezienie i przytoczenie kontrargumentów wydaje się czynnością zbyt trudną (w szczególności w sytuacji orzekania na podstawie wewnętrznego poczucia słuszności w kulturze prawnej opartej na stosowaniu prawa stanowionego). W najbardziej kompleksowym ujęciu strategia ta przybiera formę rozbudowanej wypowiedzi z wyraźnym zaznaczeniem akcentów konstytucyjnych, europejskich (zarówno w zakresie prawa, jak i orzecznictwa) czy międzynarodowych.

Obok typowych adresatów uzasadnienia - stron i sądu wyższej instancji - w przypadku formułowania jego treści w sposób problemowy rośnie rola szczególnego czytelnika, jakim jest glosator. Mając świadomość, że poruszana

\footnotetext{
${ }^{29}$ Por. orzeczenie o sygn. akt II OZ 359/13.

${ }^{30}$ NSA, w podobnej roli występuje także wojewódzki sąd administracyjny w stosunku do organu administracji.

${ }^{31}$ Sytuacja, w której sąd niższej instancji zmuszony jest de facto do orzekania sprawnego i maksymalnie poprawnego nie wpływa jednak z reguły korzystnie na jakość sporządzanych przez niego uzasadnień. Dotyczy to zwłaszcza sytuacji, w których stan sprawy będzie wymagał zastosowania klauzuli generalnej, a sędzia, obawiając się nadinterpretacji lub wręcz dokonania niepoprawnej wykładni, zrezygnuje w ogóle z jej zastosowania w rozstrzygnięciu, a tym samym nie znajdzie ona odzwierciedlenia w uzasadnieniu, znacznie je zubażając. Konstruowanie takich „bezpiecznych”, niemalże szablonowych rozstrzygnięć jest zdecydowanie szkodliwe dla praktyki stosowania prawa.
} 
w uzasadnieniu kwestia prawna może wzbudzić zainteresowanie literatury, autor bez wątpienia będzie starał się rozbudować te elementy uzasadnienia, które z dużym prawdopodobieństwem będą analizowane i oceniane przez komentatorów. Działając w ten sposób, wyprzedza on o krok spodziewaną krytykę, starając się w możliwie pełnym zakresie zaprezentować argumentację prawną oraz swój warsztat. Podobnie jak w odniesieniu do świadomości istnienia trybu odwoławczego, także i w tym przypadku autor uzasadnienia konstruuje je z przeświadczeniem, że może ono być poddane bezpośredniej analizie ${ }^{32}$.

Analogicznie rzecz ma się wówczas, gdy uzasadnienie kierowane jest do społeczeństwa, w szczególności w sprawach będących przedmiotem swoistego publicznego zainteresowania. Sytuacja ta ujawnia pozaprocesowe znaczenie uzasadnień sądowych, wykraczające poza ramy danego postępowania ${ }^{33}$. Sposób uzasadniania orzeczeń wpływa bowiem na kulturę prawną obywateli, postrzeganie przez nich prawa i postawę wobec niego: ,im wyższy poziom uzasadnień, bardziej przekonująca argumentacja, tym lepszy jest ich odbiór społeczny i lepsza ocena sądów w oczach obywateli” ${ }^{34}$. Sędzia powinien mieć świadomość, iż uzasadnienie sądowe legitymizuje do pewnego stopnia obowiązujący porządek prawny, dostosowując do tego celu nie tylko argumenty, lecz także język uzasadnień. Należy również pamiętać o niewątpliwym walorze edukacyjnym uzasadnień sądowych, z których społeczeństwo czerpie wiedzę o prawie i jego stosowaniu. $Z$ tego powodu powinno ono być możliwie kompleksowe w zakresie argumentacji i użytych środków retorycznych, w celu wyjaśnienia ewentualnych wątpliwości w sposób jasny i klarowny. Dyskursywność uzasadnienia wpływa również na przekaz medialny - a więc, jak już wspomniano, pośrednio na społeczny odbiór uzasadnienia ${ }^{35}$.

W części prawnej sąd może też skierować pod adresem prawodawcy postulaty de lege ferend $a^{36}$.

Można również zaobserwować strategie pośrednie, będące kompilacją dwóch zaprezentowanych powyżej oraz konsekwencją ich wzajemnego przenikania się (możliwe jest wtedy skierowanie uzasadnienia do szerszego kręgu

${ }^{32}$ Choć w tym przypadku występuje też szereg interesujących odrębności, wymagających osobnego opracowania.

${ }^{33}$ Szerzej na ten temat: E. Łętowska, Pozaprocesowe znaczenie uzasadnienia sqdowego, „Państwo i Prawo” 1997, z. 5, s. 3 i n.

${ }^{34}$ B. Dauter, Metodyka pracy sędziego sqdu administracyjnego, Warszawa 2011, s. 484 i n.

${ }^{35}$ Ze względu na znaczący wpływ orzeczeń NSA, poprzez traktowanie ich niekiedy jako kluczowego punktu odniesienia w sposobie wykładni prawa oraz powoływanie się na autorytet tego sądu zarówno w orzeczeniach innych składów orzekających czy sądów niższej instancji, jak i przedstawicieli nauki prawa, a także brak zinstytucjonalizowanej kontroli instancyjnej nad NSA, orzeczenia przez niego wydawane muszą charakteryzować się wyższą jakością. $Z$ założenia powinny one więc nie tylko odnosić się do realiów konkretnej sprawy, lecz nakreślać bardziej ogólny i uniwersalny sposób rozumienia danej regulacji.

${ }^{36}$ Por. w tej kwestii np. wyrok Naczelnego Sądu Administracyjnego z 21 czerwca 2011 r., I OSK 311/11. 
adresatów). Ma to miejsce m.in. w przypadku orzeczeń o charakterze precedensowym lub rozstrzygających skomplikowany problem prawny. Najpierw następuje wówczas zarysowanie ogólnego tła, wprowadzenie do ustalonego przez sędziego sposobu rozumienia i stosowania danej instytucji prawnej, a następnie - konkretyzacja z elementami dyskursywnymi w stosunku do podnoszonych zarzutów. Niekiedy uzasadnienia tworzone są również w inny sposób - pod z góry ustaloną tezę, będącą wynikiem refleksji autora uzasadnienia. Eksponowane są wówczas tylko racje przemawiające za obranym poglądem, natomiast maskowane lub wręcz przemilczane zostają argumenty przeciwne lub nieprzemawiające jednoznacznie na rzecz jednego ze stanowisk. Dzieje się tak przeważnie wtedy, gdy autor uzasadnienia ma pewność co do możliwej bezpośredniej kontroli uzasadniania (przez inny sąd lub stronę), a trudno jest mu się odnieść do wszystkich podnoszonych w toku postępowania wątków, nawet o charakterze zasadniczym dla rozstrzygnięcia.

$\mathrm{Na}$ marginesie warto jedynie zasygnalizować kwestię posługiwania się w uzasadnieniu rozstrzygnięcia techniką sprowadzającą się do przytoczenia zasady clara non sunt interpretand ${ }^{37}$ wprost lub $\mathrm{w}$ omówieniu, jako sposobem unikania przedstawiania własnej argumentacji. Tak skonstruowana część prawna pozbawiona jest swojej istoty i można ją określić jako uzasadnienie bez uzasadnienia. Z perspektywy argumentacyjnej stwierdzenie, iż dana regulacja jest jasna, ucina dalszą dyskusję, pozwalając sądowi na odstąpienie od uzasadniania czegoś rzekomo oczywistego ${ }^{38}$. Jest ona jednak wykorzystywana najczęściej tylko z pozornym przekonaniem o jasności regulacji, w celu zamaskowania rzeczywistej intencji - najczęściej uniknięcia uzasadnienia kwestii trudnej czy skomplikowanej3.

${ }^{37}$ Szerzej: T. Grzybowski, Spory wokót reguly „,clara non sunt interpretanda”, „Państwo i Prawo" 2012, z. 9, passim; Z. Tobor, W poszukiwaniu intencji prawodawcy, Warszawa 2013, s. 24 i n.; M. Zirk-Sadowski, Trzy ujęcia zasady ,,clara non sunt interpretanda” jako zakazu inicjowania interpretacji, [w:] R. Hauser, Z. Niewiadomski, A. Wróbel, System prawa administracyjnego, t. 4: L. Leszczyński, B. Wojciechowski, M. Zirk-Sadowski (red.), Wyktadnia w prawie administracyjnym, Warszawa 2012, s. 156-159.

${ }^{38}$ Sąd stosujący taki zabieg popada w sprzeczność, twierdząc, że przepisy sąjasne i nie należy dokonywać ich interpretacji, gdyż już samo takie stwierdzenie jest dokonaniem wykładni. Nie można bowiem w sposób subiektywny przypisywać niczemu właściwości obiektywnej w postaci jasności.

${ }^{39}$ Jest to szczególnie widoczne w przypadku postanowień wydawanych na posiedzeniu niejawnym w sprawach - co do zasady - mniejszej wagi, adresowanych najczęściej do bardzo wąskiego kręgu adresatów, głównie stron postępowania. Takim uzasadnieniom niejednokrotnie brakuje odzwierciedlenia fazy subsumpcyjnej, co oznacza, że przekaz sprowadza się tylko do autorytatywnych twierdzeń. Podobnie sytuacja przedstawia się przy wypełnianiu treścią klauzul generalnych. Posługiwanie się - wprost lub w sposób dorozumiany - kryterium jasności i oczywistości regulacji prawnych jako ucieczka od wskazania motywów podjętej przez siebie decyzji zdecydowanie obniża prestiż sądu w oczach adresatów uzasadnienia. 
Zupełnie osobną kategorią uzasadnień są te, które w ogóle nie mieszczą się w przedstawionych powyżej schematach - uzasadnienia bez strategii, w których trudno odgadnąć intencję autora. Potencjalni adresaci są w tym przypadku niemalże całkowicie ignorowani, a stworzenie uzasadnienia traktowane jest jedynie jako sprostanie wymogom proceduralnym nałożonym w prawie procesowym.

\section{Uzasadnienie ustne}

Ustne przedstawienie najważniejszych motywów przemawiających za podjęciem konkretnego rozstrzygnięcia (uzasadnienie ustne) zasadniczo różni się od uzasadnień sporządzanych w formie pisemnej. Różnice wynikają przede wszystkim ze specyfiki sytuacji, w jakiej jest ono tworzone i uzewnętrzniane (przygotowanie go uprzednio - przynajmniej w zarysie - lub wygłoszenie ad hoc na sali sądowej, nie zaś na posiedzeniu niejawnym). Są one widoczne w trzech zasadniczych sferach: postrzeganiu kręgu odbiorców uzasadnienia, samej kostrukcji uzasadnienia (stosunku poszczególnych elementów konstrukcyjnych do siebie) oraz szacie językowej (styl, leksyka).

Uzasadnienie ustne staje się zazwyczaj wspólnym stanowiskiem (sumą racji prezentowanych przez poszczególnych sędziów), w którym motywy orzeczenia są już wcześniej przygotowane (narada), a następnie zebrane, przetworzone $\mathrm{i}$ - jako najistotniejsze dla treści orzeczenia oraz celów, jakie chce osiągnąć sąd - komunikowane adresatom. W rezultacie uzasadnienie ustne jest w znacznym stopniu dyskursywne w stosunku do stron postępowania oraz publiczności zgromadzonej na sali rozpraw. W wypowiedzi tej sąd może bowiem bezpośrednio odnieść się do tego, co działo się w toku postępowania sądowego, w szczególności do reakcji publiczności (głównie dotyczącej niezrozumienia prawa), wypowiedzi stron itp. ${ }^{40}$ Dodatkowo warto podkreślić, że zwykle mniejszy niż w rozprawie krąg zainteresowanych podmiotów (niekiedy również innego rodzaju) uczestniczy w samym tylko odroczonym ogłoszeniu orzeczenia, podczas którego prezentowane jest uzasadnienie ustne ${ }^{41}$.

${ }^{40}$ Uzasadnienie prezentowane bezpośrednio po zamknięciu rozprawy i naradzie, pozostając w bliskim czasowym sąsiedztwie wydarzeń z sali sądowej, nie pozwala natomiast na długie rozważanie treści, którą chce się przekazać (choć oczywiste jest, iż uzasadnienie w toku narady z natury rzeczy musiało zawierać uzasadnienie poszczególnych decyzji podejmowanych w konkretnych fazach procesu stosowania prawa i jest swoistym „uzasadnieniem uzasadnienia”). Uzasadnienie prezentowane w dniu rozprawy cechuje się ponadto zwięzłością oraz wyeksponowaniem kluczowych argumentów, będących odpowiedzią na najistotniejsze wątpliwości prawne i faktyczne w sprawie, m.in. ze względu na ograniczony czas przeznaczony na rozpatrzenie każdej z nich.

${ }^{41}$ Różnice pomiędzy cechami uzasadnienia ustnego wygłaszanego $\mathrm{w}$ dniu rozprawy, a prezentowanego $\mathrm{w}$ terminie odroczonym, są mimo to $\mathrm{w}$ praktyce nieznaczne. $\mathrm{Z}$ oczywistych względów sędzia sprawozdawca (co do zasady prezentujący uzasadnienie ustne) ma więcej czasu na przygotowanie się do tej czynności, przemyślenie i wybór środków retorycznych, konstruk- 
W przypadku uzasadnienia ustnego katalog adresatów ulega istotnemu zawężeniu. Jest on nie tylko wynikiem percepcji sędziego, lecz także konsekwencją uwarunkowań proceduralnych - ze względu na spełniane funkcje procesowe uzasadnienie to nie jest dostępne szerokiemu kręgowi odbiorców. Z oczywistych względów jest ono adresowane do publiczności, która nie jest samodzielnym odbiorcą uzasadnienia pisemnego (jest ona zazwyczaj zbiorem przedstawicieli innych odbiorców, nigdy jednak wszyscy wyróżnieni potencjalni odbiorcy uzasadnienia nie są tu w pełni reprezentowani). Uzasadnienie ustne kierowane jest wprost do stron postępowania, w tym przedstawicieli organu administracji publicznej i ich pełnomocników obecnych na sali rozpraw. Sam sędzia, prezentując ustne motywy, jest w tym przypadku raczej adresatem czegoś, co można określić jako preuzasadnienie - aby przedstawić uzasadnienie ustne, musiał je wcześniej przygotować ${ }^{42}$. Jeżeli na sali obecna jest tylko jedna strona, to na nią i podnoszone przez nią racje skierowany jest ciężar argumentacji. Jeżeli nie zostanie zgłoszony wniosek o sporządzenie pisemnego uzasadnienia, w przekazie zewnętrznym pozostanie tylko treść uzasadnienia ustnego, które ma również szanse oddziaływać na tyle perswazyjnie, że orzeczenie nie zostanie zaskarżone ${ }^{43}$. W niektórych przypadkach uzasadnienie ustne jest kierowane do całego społeczeństwa za pośrednictwem mediów, które występują jako samodzielny adresat w tym zakresie, w jakim sąd - przedstawiając racje przemawiające za konkretnym podjętym rozstrzygnięciem - stara się kreślić uwagi natury ogólniejszej i kształtować rozumienie oraz świadomość prawną przedstawicieli prasy czy telewizji (zapewniając tym samym poprawność merytoryczną przekazu) ${ }^{44}$.

cji, języka oraz - co najważniejsze - argumentów. Najczęściej już wtedy równolegle do refleksji nad uzasadnieniem ustnym projektuje uzasadnienie pisemne (uzasadnienie ustne staje się wtedy streszczeniem bardziej rozbudowanej formy pisemnej). Sędzia sprawozdawca może także wskazać powody, które zadecydowały o odłożeniu ogłoszenia orzeczenia w czasie.

${ }^{42}$ Właściwie każdy z sędziów kreśli własne preuzasadnienie, które może być następnie ujawniane tylko jako zdanie większości - w ustnych motywach i pisemnym uzasadnieniu - albo jako votum separatum, jeżeli odbiega od stanowiska zajętego przez pozostałych członków składu orzekającego. Należy jednak pamiętać, że ze względu na pragmatyczne podejście do uzasadnień rzeczywiste motywy orzeczenia (wewnętrzne uzasadnienie sędziego) mogą się różnić od tych wyrażonych na zewnątrz.

${ }^{43}$ B. Dauter, op. cit., s. 397-398.

${ }^{44}$ Uzasadnienie ustne wydaje się nieco bardziej spersonalizowane w odbiorze $\mathrm{z}$ uwagi na to, że wygłasza je jeden sędzia (choć w imieniu całego składu orzekającego). Natomiast uzasadnienie pisemne, chociażby ze względu na to, iż podpisują się pod nim wszyscy sędziowie ze składu, w potocznym odbiorze może być postrzegane bardziej jako stanowisko sądu niż konkretnej jednostki (pomimo wcześniejszej konieczności kolegialnego uzgodnienia treści tych ustnych motywów). Również z tego powodu należy zwrócić uwagę na możliwość powstania rozbieżności pomiędzy wygłoszonym wcześniej uzasadnieniem ustnym a następczo formułowanym uzasadnieniem pisemnym. Nie bez znaczenia dla postrzegania uzasadnienia pozostaje także ciężar gatunkowy spraw rozpatrywanych na rozprawie, w przeciwieństwie do - zasadniczo wpadkowych - orzeczeń na posiedzeniu niejawnym. 
W strukturze uzasadnienia ustnego dochodzi do wyraźnego oddzielenia od siebie części historycznej i prawnej - zarówno pod względem konstrukcyjnym, jak i czasowym.

W przypadku uzasadnienia ustnego, będącego de facto samoistną częścią prawną rozważań sądu, właściwie nie występuje rys historyczny sprawy. Umiejscawia się go w innym momencie postępowania przed sądem - po otwarciu rozprawy i czynnościach wstępnych sędzia sprawozdawca przedstawia w swoim referacie stan ustaleń faktycznych w sprawie i to ta część jest quasi-uzasadnieniem faktycznym. Najczęściej nie jest ono ustrukturalizowane i usystematyzowane tak, jak uzasadnienie pisemne, w którym wyraźnie wyodrębnia się (nie tylko graficznie, lecz także retorycznie) część historyczną oraz część prawną. W referacie tym nie dochodzi jednak do uzasadniania w sensie ścisłym, gdyż rozstrzygnięcie nie zostało jeszcze podjęte. Interesujący wydaje się także cel referowania dotychczasowego przebiegu sprawy. Wypowiedź ta nie jest, oczywiście, kierowana do stron postępowania, które doskonale znają istotne fakty. Czynność ta podejmowana jest więc nie tylko w celu przedstawienia tych okoliczności publice obecnej na sali rozpraw, lecz aby przygotować grunt pod dalsze możliwe wypowiedzi i pytania sądu. Takie „uzasadnienie” faktyczne pełni więc wyraźną rolę służebną w stosunku do tego, co będzie się działo na sali rozpraw i stanowi wyłącznie wstęp, tworząc tło i kontekst dla dalszych rozważań.

Ustne podanie zasadniczych powodów rozstrzygnięcia jest już natomiast uzasadnieniem prawnym właściwym. Takie uzasadnienie ma za zadanie zwięźle przedstawić najważniejsze motywy stojące za rozstrzygnięciem, aby nie stwarzać wrażenia jego autorytatywności. Warto podkreślić, że wagi uzasadnienia ustnego nie osłabia fakt odroczenia ogłoszenia orzeczenia i przedstawienia tych motywów w odrębnym terminie niż sama rozprawa sądowa ${ }^{45}$.

Uzasadnienie ustne cechuje się również innymi właściwościami języka, z oczywistych względów odmiennymi od języka uzasadnienia pisemnego - nieco inną składnią (właściwą dla wypowiedzi mówionej) i użyciem prostszych sformułowań w celu dostosowania go do adresata. W sytuacji odroczenia ogłoszenia orzeczenia sędzia prezentujący uzasadnienie ustne ma więcej czasu do namysłu nad treścią i konstrukcją (w szczególności argumentacyjną) uzasadnienia. Z uwagi na częste reprezentowanie stron przez profesjonalnych pełnomocników, a co za tym idzie, bardziej jednorodny zbiór podmiotów na sali rozpraw, ustne podanie motywów rozstrzygnięcia może odbywać się językiem profesjonalnym. W stosunku do strony, która nie jest reprezentowana przez profesjonalistę, wskazane jest zastępowanie zwrotów typowo prawniczych sformułowaniem opisowym. Niemniej jednak podstawową dyrektywą jest zawsze zrozumiałość przekazu. Dlatego też w uzasadnieniu ustnym nie ma miejsca na popis sztuki retorycznej

${ }^{45} \mathrm{O}$ wzrastającej roli uzasadnienia ustnego zob. S. Dąbrowski, A. Łazarska, Uzasadnianie orzeczeń sqdowych w procesie cywilnym, „Przegląd Sądowy” 2012, nr 3, passim. 
sędziego i używanie np. paremii łacińskich. Odmiennie sytuacja przedstawia się wówczas, gdy wśród publiczności, a w szczególności stron postępowania, znajdują się również osoby reprezentujące innych nieprofesjonalnych adresatów w tym przypadku uzasadnienie przedstawiane jest najczęściej przy użyciu mniej specjalistycznego języka (co nie oznacza, że umniejsza to powagę sądu, a wręcz przeciwnie - odpowiada potrzebie społecznego zaufania do wymiaru sprawiedliwości). Przekaz powinien być bowiem dostosowany do jego adresata ${ }^{46}$.

\section{Podsumowanie}

Na zakończenie warto zastanowić się nad możliwością praktycznego zastosowania przedstawionych wyżej rozważań. W obliczu wielości adresatów, czynników ich określających i wzajemnych zależności między nimi, odpowiednie skonstruowanie uzasadnienia jest z pewnością czynnością trudną i złożoną. Przede wszystkim należy jednak uświadomić sobie, że istnienie jednej prawidłowej strategii, odpowiedniej dla wszystkich adresatów uzasadniania, może okazać się co najmniej dyskusyjne. Zależnie od sytuacji należy bowiem raczej stosować różnorodne strategie, a co za tym idzie, techniki tworzenia uzasadnienia. Kluczową wskazówką jest zidentyfikowanie kręgu adresatów w konkretnej sprawie i obranie wobec nich określonej strategii tworzenia uzasadnienia, zdeterminowanej celem przekazu i ogólnymi funkcjami uzasadnienia (w szczególności legitymizacją i perswazją). Trzeba również pamiętać, że powstanie idealnego uzasadnienia (uwzględniającego wszystkich adresatów, wszystkie funkcje oraz pozostałe czynniki wpływające na kształt uzasadnienia) nie jest realnie możliwe. Ograniczoność zasobów, jakimi dysponuje twórca uzasadnienia (czas, warsztat pisarski, percepcja itp.), pozwala bowiem jedynie na uwzględnienie tych aspektów, które w jego ocenie są najważniejsze dla danej wypowiedzi. W konsekwencji, podstawową dyrektywą postępowania przy sporządzaniu uzasadnienia wydaje się ustalenie przez autora właściwych proporcji między narzędziami, jakie posiada oraz celami, jakie chce osiągnąć.

${ }^{46}$ Ciekawe wydaje się również to, że gdy przy rozpoznawaniu danej sprawy na posiedzeniu jawnym nie były obecne strony ani publiczność i nie wygłasza się uzasadnienia ustnego, w protokole rozprawy bez względu na to umieszcza się wzmiankę, będącą swoistym rytualizmem, o podaniu ustnych motywów rozstrzygnięcia (niezasadne byłoby bowiem ich wygłaszanie tylko pod adresem sędziów, którzy doskonale znają te motywy). 